At-Turats

Jurnal Pemikiran Pendidikan Islam

journal homepage: http://jurnaliainpontianak.or.id/index.php/atturats

\title{
Pembelajaran Berkarakter Dalam Masyarakat Ekonomi Asean (MEA)
}

\author{
Isyatul Mardiyati \\ Dosen Jurusan PGRA \\ Fakultas Tarbiyah Dan Ilmu Keguruan (FTIK) \\ Institut Agama Islam Negeri (IAIN) Pontianak \\ isyamar_zein@yahoo.com
}

\begin{abstract}
A B S T R A K
In the middle of technology advances, transportation and communication. Various south east asia country is facing crisis of cultural values of nationalities identity, this issue not only make a nation loses dignity as an independent, this even prediction to born a new universal identity that dull the old characters.

As a framework to fortify young generations from globalization development that eroded cultural values character of nation, hopefully characters learning is an alternative way to face various kinds of multi demention problem faced by Indonesian and southeast asia.
\end{abstract}

Key wards: Characters learning, $M E A$

\section{PENDAHULUAN}

Seiring dengan diberlakukannya Masyarakat Ekonomi ASEAN (MEA). Indonesia tidak hanya dihadapkan pada perputaran bebas arus barang dan jasa. Namun juga pada krisis terbuka pergesaran nilai-nilai karakter yang mengancam lunturnya indentitas kepribadian bangsa, sebagai akibat dari ekonomi pasar tunggal ASEAN yang berimplikasi pada penyatuan kekuatan sentra yang semakin memudarkan kekuatan lokal the passing of local community). Padahal eksistensi suatu bangsa sangat ditentukan oleh karakter yang melekat pada dirinya.

Selain itu, dalam dunia pendidika modern Indonesia, pemikiran-pemikran pendidikan masih di dominasi oleh karakter pendidikan Barat yang menawarkan berabagai konsep pendidikan yang sarat dengan teori psikologi dan filsafat pendidikan. Namun konsep yang ditawarkan tersebut sebenarnya tidak sepenuhnya sesuai dengan adat istiadat serta budaya ketimuran. Sehingga hasilnya, konsep-konsep pendidikan yang ditawarkan tidak mampu melahirkan manusia yang sadar akan tugas dan tujuannya sesuai dengan ciri khas masyarakatnya. Dengan demikian nilai-nilai pendidikan Barat bukan merupakan dasar yang terbaik untuk melakukan tindakan, bukan karena nilai-nilai tersebut tidak penting, melainkan karena nilai-nilai tersebut tidak berlaku secara universal. Apabila nilainilai tersebut dipaksakan untuk diberlakukan kepada setiap orang, akan terjadi "imperialisme moral," pemaksaan suatu nilai yang bersifat khusus kepada orang lain yang tidak sepaham. ${ }^{1}$

\footnotetext{
${ }^{1}$ Ali Masykur Musa. Membumikan Islam
} 
Berdasarkan hal tersebut, karakter atau watak suatu bangsa harus diawali dan bersumber dari nilai-nilai yang digali, tumbuh dan berkembang dari budaya Indonesia yang telah berakar dari keyakinan masyarakat Indonesia sendiri dan bersumber dari falsafah hidup bangsa. Sehingga mereka yang berstatus "lebih" di dalam berbagai aspek kehidupan harus dapat mentransformasikan watak pendidikan kepada yang dibawahnya. Lebih yang dimaksud adalah lebih di bidang umur (senioritas), jabatan, kepangkatan, kecakapan, kepandaian, kekayaan, kekuatan dan keadaban.

\section{MASYARAKAT EKONOMI}

\section{ASEAN DAN PEMBELAJARAN BERKARAKTER}

\section{Tantangan Pendidikan dalam}

\section{Masyarakat Ekonomi ASEAN}

Lahirnya Masyarakat Ekonomi ASEAN (MEA) pada tahun 2015, memungkinkan adanya arus mobilitas perdagangan barang dan jasa antar sesama negara anggota. Kesepakatan ini tidak hanya berdampak pada sektor real seperti ekonomi dan pertahanan di kawasan Asia Tenggara, melainkan juga sektor-sektor vital lainnya termasuk pendidikan yang telah dianggap sebagai lokomotif andalan pembangunan kualitas Sumber Daya Manusia (SDM) di suatu negara.

Saat ini sektor pendidikan di Indonesia masih menghadapai berbagai tantangan dan hambatan dalam mengahadapi Masyarakat Ekonomi ASEAN (MEA), tantangan tersebut berasal dari dalam (internal) maupun dari luar (eksternal). Adapun faktor-faktor tersebut antara lain:

Nusantara: Respons Islam terhadap Isu-Isu Aktual. (Jakarta: PT. Serambi Ilmu Semesta. 2014). hlm. 246. a. Kurang meratanya porsi pembangunan. Ketikamerataan pembangunan dan masalah keadilan merupakan salah satu faktor munculnya kesenjangan sosial anatar pusat dan daerah. Pembangunan yang masih terkonsentrasi di kawasan-kawasan yang dekat dengan pusat pelayanan menyebabkan tidak meratanya pembangunan antara di pedesaan dengan dan di perkotaan, bahkan antara pulau jawa dan luar jawa. Dampakanya fasilitas-fasilitas umum termasuk pendidikan masih belum dapat dinikmati secara merata yang pada akhirnya bermuara pada kualitas sumber daya manusia yang belum tergali secara maksimal.

b. Terbatasnya jumlah tenaga dan kompetensi pendidik. Dalam bidang pendidikan, Indonesia masih dihadapkan dengan persoalan klasik seperti kekurangan jumlah (shortage), distribusi tidak seimbang (unbalanced distribution), kualifikasi dibawah standar (under qualification), kurang kompeten (low competences), serta ketidak sesuaian antara kualifikasi pendidikan dengan bidang yang diampu (mismatched). ${ }^{2}$ Hal lain yang menjadi persoalan adalah orang yang benar-benar karena panggilan hatinya untuk menjadi guru amatlah sedikit, yang banyak adalah mereka yang "asal dapat kerja". ${ }^{3}$ Bahkan, Niels Mulder (2003) menyebutkan bahwa persiapan guru tidak memadai; kira-kira $50 \%$ dari para guru kualifikasinya kurang dan hanya setengah-setengah saja memahami bahan

${ }^{2}$ Sofia Sinaga dan Basuki. Bahasa Indonesia: Couursebook. (United Kingdom: Cambridege University Press. 2016). hlm. 165.

${ }^{3}$ Ahmad Syafii Maarif. Islam dalam Bingkai keindonesiaan dan Kemanusiaan: Sebuah Refleksi Sejarah. (Bandung: PT. Mizan Pustaka. 2009). hlm. 217. 
yang sedang mereka ajarkan. ${ }^{4}$

c. Rendahnya kualitas lulusan. Persoalan relatif rendahanya mutu lulusan pada tiap level pendidikan yang menciptakan relatif rendahnya potensi tenaga kerja untuk dapat bersaing di pasar bebas. Hal ini ditenggarai belum siapnya lembaga pendidikan dalam memenuhi tuntutan masyarakat, kompetisi global dan lokal, akreditasi nasional dan internasional, konflik kepentingan, takut untuk berubah, dan sumber daya terbatas (conflict of interet, worry to change, limited reseources). ${ }^{5}$

d. Rendahnya daya saing di pasar global. Berdasarkan laporan World Competitiveness Report 2008, daya saing Indonesia berada di urutan ke 55. Sedangkan pada 2007 Indonesia berada di urutan 54. Pada 2006 ada diurutan 50 dan pada 2005 ada di urutan 74. Sementara negara ASEAN lainnya seperti Singapura berada pada urutan 5, Malaysia di urutan 21, Thailand di uru$\tan 34$, dan Brunei Darussalam pada urutan 39. 6 Dengan demikian makam sikawasan ASEAN, Indonesia belum mampu secara optimal menghadirkan sarjana pendidikan yang mampu berkompetensi dan siap pakai di dunia kerja. Terlebih bagi Indonesia yang secara prestasi akademik (academic strength) masih tertinggal di bawah Singapura, Brunei Darussalam dan Malaysia. ${ }^{7}$

4 Niels Mulder. Terj. A. Widyamartaya. Wacana Publik Asia Tenggara. (Yogyakarta: Kanisius. 2003). hlm. 287.

5 Erika Setyanti Kusumaputri. 2005. Komitmen Pada Perubahan Organisasi: Perubahan Organisasi dalam Perspektif Islam dan Psikologi. (Yogyakarta: Deepublish. 2005). hlm. 29.

6 Mohammad Ali. Pendidikan Untuk Pembangunan Nasional: Menuju Bangsa Indonesia yang Mandiri dan Bersaing Tinggi. (Jakarta: Grasindo. 2009). hlm. 119.

7 Salah satu hal menarik dari pendidikan di negara-negara ASEAN, dahulu Malaysia adalah
Berdasarkan berbagai persoalan di atas, diperlukan sebuah upaya guna mempermudah akses masyarakat dalam memenangi persaingan di pasar bebas regional ASEAN, yakni: 1) dalam bidang pendidikan diperlukan rekontruksi kembali muatan materi pelajaran yang berbasis karakter pendidikan masyarakat ASEAN tanpa menghilangkan karakter bangsa Indonesia. 2) kegiatan pendidikan diarahkan pada kebutuhan pasar di negara-negara ASEAN. 3) peningkatan kemampuan dibidang penguasaan bahasa internasional. 4) pemerataan infrastritur perekonomian masyarakat, dan 5) menjalin kerjasama kemitraan pendidikan dengan lembaga pendidikan yang berkualitas di negara ASEAN.

\section{Pembelajaran Berkakter}

Niels Mulder (2003) menyebutkan bahwa sering, bahan pelajaran tidak selaras dengan kenyataan hidup. Fakta bahwa perkembangan masyarakat kota digerakan pasar tidak tercerminkan dimana pun dalam bahan pengajaran; hal ini juga jelas terlihat dari dimasukkannya pendidikan nilai belum lama ini. Di Muang Thai, tekanan terlalu besar yang diberikan pada perilaku baik merupakan gema dari pembaruan kurikulum yang bersifat reaksioner pada tahun 1978. Di Indonesia, Pendidikan Moral Pancasila dimasukan pada tahun yang sama, sedangkan program Filipina menjadi remi baru tahun 1989. Dengan kata lain, para siswa tidak dipersiapkan betul-betul untuk membangun daya cipta, hidup modern, atau kemandirian mental dan moral. Dari segi akademik, mereka tidak dilatih dengan baik; mereka hanya

negara yang banyak mengirim mahasiswanya ke Indonesia, serta mendatangkan guru dari Indonesia ke Malaysia. Namun di awal tahun 2000-an, justru banyak mahasiswa Indonesia yang mengikuti pendidikan di Malaysia. 
menghafalkan saja sejumlah besar kata sekar tanpa wawasan teoritis bagaimana istilahistilah itu berhubungan. Hal ini juga terlihat jelas di Indonesia: disini kita temukan banyak sekali kolom koran berkepala angin yang dengan jelas dipengaruhi oleh indoktrinasi yang sama-sama konsisten. ${ }^{8}$

Pertama, karkter adalah sesuatu yang dipelajari bukan bawaan alamiah yang dibawa sejak lahir. Sehingga karater ini dapat berkembang melalui proses pembelajaran dan pembiasaan. Kedua, unsur-unsur yang membentuk karakter suatu suku bangsa merupakan suatu nilai luhur yang khas dari suatu bangsa itu sendiri yang diwujudkan dalam adat istiadat, cita-cita hidup dan kearifan lokal. Ketiga, setiap karakter memiliki kelebihan dan kekurangan, sehingga penguatan dan penanaman nilai-nilai luhur karakter suatu suku bangsa dalam kehidupan bermasyarakat, berbangsa dan bernegara perlu untuk direalisasikan dalam kehidupan sehari-hari, baik melalui proses sosialisasi, pendidikan, pemberdayaan, pembudayaan dan kerjasama. ${ }^{9}$

Asla (dalam Wiguna, 2014: 154) menyatakan bahwa pendidikan karakter adalah usaha menanamkan nilai-nilai (value) yang baik dan positif dalam diri anak didik. Dalam konteks pendidikan di Indonesia nilai-nilai tersebut terdapat dalam ajaran agama, pancasila, budaya bangsa Indonesia, dan tujuan pendidikan nasional. ${ }^{10}$

Menurut Asmani (dalam Rahayu, 2015: 21) menyebutkan bahwa, tujuan pendi-

8 Niels Mulder. loc. cit. hlm. 287.

9 Bungaran Antonius Simanjutak. Karakter Batak Masa Kini dan Masa Depan. (Jakarta: Yayasan Pustaka Obor Indonesia. 2014). hlm. 163.

${ }^{10}$ Alivermana Wiguna. Isu-Isu Kotemporer Pendidikan Islam. (Yogyakarta: Deepublish. 2014). hlm. 154. dikan karakter adalah untuk membentuk pribadi anak supaya menjadi manusia yang baik, yaitu masyarakat dan negara yang baik. Hal ini sejalan dengan pendapat Elfindri (2012) yang menyatakan bahwa tujuan pendidikan karakter adalah pembentukan prilaku keseharian dalam kaitannya dengan item-item yang dapat masuk ke dalam dimensi kognitif, afektif dan psikomotorik. Kaitannya dengan soft skill, pendidikan karakter merupakan proses pembuatan sikap yang mengarah pada berfungsinya ilmu dan keterampilan secara optimal. $^{11}$

Adapun nilai-nilai pendidikan karakter dalam sistem pendidikan nasional sebagaimana dikemukakan oleh Munif Chatib (2012: 84), adalah sebagai berikut :12

a. Religius: sikap dan perilaku dalam melaksanakan ajaran agama yang dianut, toleran terhdap pelaksanaan ibadah agama lain, dan hidup rukun dengan pemeluk agama lain.

b. Jujur: perilaku yang didasarkan pada upaya menjadikan diri sebagai orang yang selalu dapat dipercaya dalam perkataan, tindakan dan pekerjaan.

c. Toleransi: sikap dan tindakan yang menghargai perbedaan agama, suku, etnis, pendapat, sikap dan tindakan orang lain yang berbeda dengan dirinya.

d. Diiplin: tindakan yang menunjukan perilaku tertib dan patuh pada berbagai ketentuan dan peraturan.

e. Kerja keras: perilaku yang menunjukkan upaya sungguh-sunggu dalam mengatasi

${ }^{11}$ Wahyuningsih Rahayu. Model Pembelajaran Komeks: Bermuatan Nilai-Nilai Pendidikan Katrakter Aspek Membaca Intensif di SD. (Jakarta: Deepublish. 2015). hlm. 22.

${ }^{12}$ Munif Chatib. 2012. Orang Tuanya Manusia: Melejitkan Potensi dan Kecerdasan dengan Menghargai Fitrah Anak. (Jakarta: Mizan. 2012). hlm. 84. 
berbagai hambatan belajar dan tugas, serta menyelsaikan tugas dengan sebaik-baiknya.

f. Kreatif: berpikir dan melakukan sesuatu untuk menghasilkan cara atau hasil baru dari sesuatu yang telah dimiliki.

g. Mandiri: sikap dan perilaku yang tidak mudah bergantung pada orang lain dalam menyelesaikan tugas-tugas.

h. Demokratis: cara berpikir, bersikap, dan bertindak yang menilai persamaan derajat dihubungkan dengan hak dan kewajiban dirinya dan orang lain.

i. Rasa ingin tahu:sikap dan tindakan yang selalu berupaya untuk mengetahui lebih mendalam dan luas sesuatu yang dipelajari, dilihat dan didengar.

j. Semangat kebangsaan: cara berpikir, bertindak dan berwawasan yang menempatkan kepentingan bangsa dan negara di atas kepentingan diri dan kelompoknya.

k. Cinta tanah air: cara berpikir, bersikap, dan berbuat yang menunjukan kesetiaan, kepedulian, dan peghargaan yang tinggi terhadap bangsa, lingkungan fisik, sosial, budaya, ekonomi, dan politik bangsa.

1. Menghargai prestasi:sikap dan tindakan yang menodrong diri sendiri untuk menghasilkan sesuatu yang berguna bag masyarakat dan mengakui serta menghormati keberhasilan orang lain.

m.Bersahabat/komunikatif: tindakan yang memperlihatkan rasa senang bicara, bergaul, dan bekerjasama dengan orang lain.

n. Cinta damai:sikap, perkataan, dan tindakan yang menyebabkan orang lain merasa senang dan aman atas kehadiran dirinya.

o. Gemar membaca:kebiasaan menyediakan waktu untuk membaca berbagai bacaan yang memberikan kebaikan bagi dirinya.

p. Peduli lingkungan: sikap dan tindakan yang selalu berupaya mencegah keru- sakan lingkungan alam di sekitarnya dan mengembagkan upaya untuk memperbaiki kerusakan alam yang sudah terajadi.

q. Peduli sosial: sikap dan tindakan yang selalu ingin memberikan bantuan kepada orang lain dan masyarakat yang membutuhkan.

r. Tanggung jawab: sikap dan perilaku seseorang untuk melaksanakan tugas dan kewajiban yang seharusnya dia lakukan terhadap diri sendiri, masyarakat, lingkungan (alam, sosial dan budaya), negara, dan Tuhan Yang Maha Esa.

Nilai-nilai pendidikan karakter perlu diintegrasikan dalam pembelajaran para pendidik di kelas pada semua bidang studi dalam bentuk kurikulum yang terpadu. Nilai-nilai ini dapat diinternalisasikan mulai dari kegiatan pembukaan, inti hingga kegiatan penutup. Proses menanamkan nilai-nilai ini dapat dilakukan pada aspek kognitif dan afektif melalui pemahaman materi dan penerapan sikap dalam kehidupan sehari-hari yang dapat dinilai dari proses pembelajaran maupun pembiasaan.

Melihat realitas tersebut Moh. Suardi (2015) menyatakan pentingnya menggagas pendidikan Islam berbasis pluralism dengan menonjolkan beberapa karakter sebagai berikut;

a. Pendidikam Islam harus mempunyai karakter sebagai lembaga pendidikan umum yang bercirikan Islam. Artinya, disamping menonjolkan pendidikannya dengan penguasaan atas ilmu pengetahuan, namun karakter keagamaan juga menjadi bagian integral dan harus dikuasi serta menjadi bagian

b. Pendidikan Islam juga harus mempunyai karakter sebagai pendidikan yang berbasis pada pluralitas. Artinya, bahwa pendidikan 
yang diberikan kepada siswa tidak menciptakan suatu pemahaman yang tunggal, termasuk di dalammnya juga pemahaman tentang realitas keberagamaan. Kesadaran pluralisme merupakan suatu keniscayaan yang harus disadari oleh setiap pesrta didik. Tentunya kesadaran tersebut tidak lahir begitu saja, namun mengalami proses yang sangat panjang, sebagai realitas pemahaman yang komprehensif dalam melihat suatu fenomena.

c. Pendidikan Islam harus mempunyai karakter sebagai lembaga pendidikan yang menghidupkan sistem demokrasi dalam pendidikan. Sistem pendidikan yang memberikan keluasaan pada siswa untuk mengekspresikan pendapatnya secara bertanggungjawab. Sekolah memfasilitasi adanya "mimbar bebas", dengan memberikan kesempatan kepada civitas untuk berbicara atau mengkritik tentang apa saja, asal bertanggung jawab. Tentunya sistem demokrasi ini akan memberikan pendidikan pada siswa tentang realitas sosial yang mempunyai padangan dan pendapat yang berbeda. Disisi yang lain, akan membudayakan "reasoning" bagi civitas di lembaga pendidikan Islam. ${ }^{13}$

\section{Pendidikan Islam yang Berkarakter}

Pendidikan memillik peranan yang sangat penting di dalam kemajuan dan kemunduran kualitas sumber daya manusia di suatu bangsa, sehingga jika kualitas sumber daya manusianya buruk maka sistem dan metode pendidikan yang berlaku di negara tersebut merupakan sistem dan metode pendidikan yang buruk. Sebaliknya jika kualitas sumber daya manusianya baik maka, sudah

${ }^{13}$ Moh. Suardi. 2015. Ideologi Politik Pendidikan Kontemporer.Yogyakarta: Deepublish. Hlm. 192 - 193. dapat dipastikan bahwa sistem dan metode pendidikan yang berlangsung di negara itu juga baik.

Permasalahan yang ada dan muncul saat ini adalah bagaimana cara atau metode pelaksanaan dalam pendidikan agama Islam akan dapat lebih berguna dalam mewujudkan genenerasi penerus bangsa yang berkualitas, unggul lahir dan batin serta berdaya saing tinggi, sebagai realisasi efektivitas pembelajaran pendidikan Islam yang berkompeten. Mengingat kemajuan suatu bangsa tidak hanya dapat mengandalkan faktor sumber daya alamnya saja, melainkan juga kualitas sumber daya manusianya juga. Inilah yang dikhawatirkan terjadi pada Indonesia jika hanya menyandarkan pada sumber daya alam saja, maka apa yang terjadi pada negara lain tidak tertutup kemungkinan akan terjadi pada masyarakat Indonesia. Hal ini sebagaimana diungkapkan oleh Mujamil Qomar (2005: 23) bahwa beberapa negara Arab, seperti Saudi Arabia dan Kuwait secara ekonomi mencapai kemajuan, tetapi karena tidak ada upaya maksimal untuk mengembangkan metode, akhirnya mereka tidak dapat mencapai kemajuan ilmu pengetahuan. Kemajuan ekonomi mereka tidak diikuti kemajuan ilmu pengetahuan, sehingga mereka kaya, tetapi sekedar menjadi konsumenn terhadap ilmu pengetahuan Barat. ${ }^{14}$

Sistem pendidikan Islam merupakan solusi dasar untuk mengganti sistem pendidikan yang bersifat sekuler. Dimana pendidikan Islam merupakan upaya sadar, terstruktur, terprogram dan sistematis untuk membentuk manusia berkarakter, yaitu manusia yang: 1) berkepribadian Islam, 2) menguasai tsaqofah Islam, 3) menguasai ilmu kehidupan, 4)

${ }^{14}$ Mujamil Qomar. Epistemologi Pendidikan Islam: Dari Metode Rasional Hingga Metode Kritik. (Jakarta: Penerbit Erlangga. 2005). hlm. 23. 
memiliki keterampilan yang memadai. ${ }^{1516}$

Menurut Mohammad Tholhah Hasan (dalam Asrori S. Karni, 2009: 413), ${ }^{17}$ pendidikan Islam sebagai kunci jawaban dalam membangu peradaban di era globalisasi harus mempunya karakter sebagai berikut: $\mathrm{Per}$ tama, dinamik, yang berarti sebuah keadaan yang terus bergerak maju dan berubah sejalan dengan tantangan yang dihadapi dan dalam menjawab perkembangan dan kemajuan ilmu pengetahuan dan tenologi serta perubahan kehidupan masyarakat. Kedua, relevan, yakni sesuai dengan tuntutan kebutuhan hidup umat (social demand), kebutuhan perjuangan dan kebutuhan pembangunan bangsa di tengah-tengah persaingan global. Ketiga, professional, dalam rekrutmen ketenagaan, dalam manajemen kependidikan, dalam proses pembelajaran, dalam kualitas out put dan akuntabilitasnya serta dalam pemberdayaan teknologi kependidikan. Keempat, kompetitif, siap bersaing dalam penampilan, dalam inovasi program, dalam membangun karakter dan kepribadian, dan kualitas produk dengan pendidikan-pendidikan lain.

\section{PENUTUP}

Berdasarkan berbagai penjelasan di atas, dapat disimpulkan bahwa pembelajaran berkarakter masih sangat diperlukan dalam kehidupan bermasyarakat, berbangsa

\footnotetext{
${ }^{15}$ Adanya ketertinggalan dalam kemajuan pendidikan Islam, hal ini dikarenakan terjadinya indoktrinisasi dan penyempitan pemahaman tentang Islam yang hanya sebatas pada aspek ukhrawi dan terpisah dengan kehidupan duniawai.

${ }^{16}$ Tim Dosen PAI. Bunga Rampai Penelitian dalam Pendidikan Agama Islam. (Yogyakarta: Deepulish. 2016). hlm. 64.

${ }^{17}$ AsroriS. Karni. Etos Studi Kaum Santri: Wajah Baru Pendidikan Islam.(Jakarta: PT. Mizan Pustaka. 2009). hlm. 413.
}

dan bernegara. Sehingga, konsep pendidikan Islam dalam hal ini masih menjadi alterntif pilihan utama sebagai sistem dan cara hidup (style of life) dalam rangka memperoleh kehidupan yang bahagia di dunia dan di akhirat berdasarkan pada karakter mausia yang Islami.

Lebih lanjut, keberhasilan pendidikan juga tidak terlepas dari aspek kepemimpinan (leadership). Sehingga dalam hal ini para pembuat kebijakan (policy maker) yang dipilih hendaklah merupakan mereka yang berpihak pada pendidikan dan bukan mereka yang tidak memiliki visi terhadap dunia pendidikan. Memilih pejabat atau pemimpin yang berkarakter dan berkeadilan adalah salah satu upaya dalam meningkatkan pendidikan politik rakyat.

\section{DAFTAR PUSTAKA}

Ahmad Syafii Maarif. 2009. Islam dalam Bingkai keindonesiaan dan Kemanusiaan: Sebuah Refleksi Sejarah. Bandung: PT. Mizan Pustaka.

Ali Masykur Musa. 2014. Membumikan Islam Nusantara: Respons Islam terhadap Isu-Isu Aktual. Jakarta: PT. Serambi Ilmu Semesta.

Alivermana Wiguna. 2014. Isu-Isu Kotemporer Pendidikan Islam. Yogyakarta: Deepublish.

AsroriS. Karni. 2009. Etos Studi Kaum Santri: Wajah Baru Pendidikan Islam. Jakarta: PT. Mizan Pustaka.

Bungaran Antonius Simanjutak. 2014. Karakter Batak Masa Kini dan Masa Depan. Jakarta: Yayasan Pustaka Obor Indonesia.

Erika Setyanti Kusumaputri. 2005. Komitmen Pada Perubahan Organisasi: Perubahan Organisasi dalam 
Perspektif Islam dan Psikologi. Yogyakarta: Deepublish.

Mohammad Ali. 2009. Pendidikan Untuk Pembangunan Nasional: Menuju Bangsa Indonesia yang Mandiri dan Bersaing Tinggi. Jakarta: Grasindo.

Moh. Suardi. 2015. Ideologi Politik Pendidikan Kontemporer.Yogyakarta: Deepublish.

Mujamil Qomar. 2005. Epistemologi Pendidikan Islam: Dari Metode Rasional Hingga Metode Kritik. Jakarta: Penerbit Erlangga.

Munif Chatib. 2012. Orang Tuanya Manusia: Melejitkan Potensi dan Kecerdasan dengan Menghargai Fitrah Anak. Jakarta: Mizan.

Niels Mulder. Terj. A. Widyamartaya. 2003. Wacana Publik Asia Tenggara. Yogyakarta: Kanisius.

Sofia Sinaga dan Basuki. 2016. Bahasa Indonesia: Couursebook. United Kingdom: Cambridege University Press.

Tim Dosen PAI. 2016. Bunga Rampai Penelitian dalam Pendidikan Agama Islam. Yogyakarta: Deepulish.

Wahyuningsih Rahayu. 2015. Model Pembelajaran Komeks: Bermuatan Nilai-Nilai Pendidikan Katrakter Aspek Membaca Intensif di SD. Jakarta: Deepublish. 